\title{
ОСОБЛИВОСТІ РЕАЛІЗАЦІЇ МОДЕЛЕЙ ФРАЗЕОЛОГІЗОВАНИХ РЕЧЕНЬ У ТВОРАХ БОГДАНА ЛЕПКОГО 1
}

Статтю присвячено розгляду фразеологізованих речень у творах Богдана Лепкого. Виділено моделі фразеологізованих речень у прозі письменника; установлено їх семантику; визначено абсолютну частоту вживання з урахуванням розмежування з омонімічними нефразеологізованими реченнями. Дослідження виконано на матеріалі корпусу текстів Богдана Лепкого.

Синтаксичні фразеологізми у прозових текстах письменника є яскравими засобами експресивного синтаксису, за допомогою яких автор передає оцінне, модальне, заперечне або акиентувальне значення. Він використовує 18 моделей синтаксичних фразеологізмів, 3-поміж яких найбільш продуктивними виявилися Який (уже/вже/же/ж) $N_{l}$ Cор, Як (же/тут) (N3) не

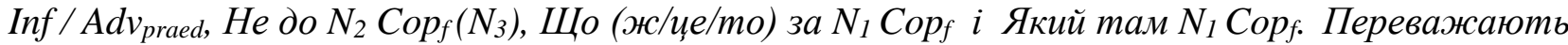
речення з двочленним стрижневим компонентом.

Синтаксичні фразеологізми $\epsilon$ багатофункиійними одинииями, у текстах Богдана Лепкого вони виконують експресивну, фатичну, коректувальну й аргументативну функиї.

Ключові слова: Богдан Лепкий, корпус текстів, мовна особистість, модель речення, прагматика, семантика, синтаксис, синтаксичний фразеологізм, фразеологія, фразеологізоване речення.

Постановка наукової проблеми та її актуальність. Сучасні дослідження 3 лінгвоперсонології зосереджені на вивченні мовної особистості, яку визначають як особливий цілісний феномен, що охоплює «сукупність усіх мовних здібностей і реалізацій особистості» (Загнітко 4). У межах цього напряму колектив дослідників Донецького національного університету імені Василя Стуса під керівництвом Анатолія Загнітка працює над науковим проєктом «Об’єктивна і суб'єктивна мовносоціумна граматика: комунікативно-когнітивний та прагматико-лінгвокомп’ютерний виміри» (0118U003137).

Особлива увага лінгвістів сфокусована на вивченні різних аспектів і рівнів мови видатних лінгвоперсон, до яких, зокрема, належить український письменник Богдан Лепкий. Актуальність пропонованого дослідження мотивована двома чинниками: 1) фразеологічні одиниці різних типів $є$ яскравими маркерами мовлення особистості; 2) фразеологізовані речення $\epsilon$ цікавим виявом взаємопроникнення різнорівневих мовних одиниць, дійовим засобом експресивного синтаксису, за допомогою якого автор досягає потрібного впливу на читача або слухача.

Аналіз досліджень наукової проблеми. Вивчення мови видатних особистостей має в Україні давні традиції. Неординарна постать Богдана Лепкого, безу-

\footnotetext{
1 Дослідження виконано в межах фундаментального наукового проєкту «Об’єктивна і суб'єктивна мовносоціумна граматика: комунікативно-когнітивний та прагматико-лінгвокомп'ютерний виміри» (0118U003137) Донецького національного університету імені Василя Стуса Міністерства освіти і науки України.
} 
мовно, не раз привертала увагу мовознавців (Горох; Діц; Кравченко-Дзондза; Ткачук та ін.). Фразеологізми у творах Богдана Лепкого були предметом аналізу в низці досліджень. Так, Тетяна Свердан виділила усічені фразеологізми у трилогії Богдана Лепкого «Мазепа» (Свердан, “Спосіб трансформації фразеологізмів"; Свердан "Усічені фразеологізми”); Тетяна Мішиньова запропонувала класифікацію фразеологізмів у цій же трилогії, розглянула трансформації народних фразеологічних одиниць та індивідуально-авторські новотвори (Мішиньова). Комплексно фразеологію письменника (у зіставленні із фразеологією Уласа Самчука) проаналізовано в циклі досліджень Тетяни Здіховської: встановлено функційно-стильові й семантичні властивості фразеологізмів різних типів 3 послідовним розмежуванням загальномовних і діалектних фразеологізмів, різновидів трансформацій і напрямів творення індивідуально-авторських фразеологічних одиниць та ін. (Здіховська, “Фразеологія прозових творів”; Здіховська, “Фразеологія української прози”; Здіховська, Горбач).

Грунтовним і скрупульозним є лексикографічне опрацювання фразеологізмів Богдана Лепкого в словнику за редакцією Стефанії Панцьо (Фразеологізми у творах Богдана Лепкого). Укладачі цієї праці прагнули подати «усі фразеологічні одиниці, прислів'я, приказки і т. ін., ужиті у творах Богдана Лепкого» (Фразеологізми у творах Богдана Лепкого 5). Водночас попри заявлений широкий підхід до розуміння фразеології в жодному з цих досліджень фразеологізовані речення не відбито.

Фразеологізовані речення (або синтаксичні фразеологізми) - конструкції, що складаються «із двох пов'язаних ідіоматично компонентів - незмінного (стрижневого) і змінного; граматичні зв'язки і прямі лексичні значення слів у такому реченні послаблені або втрачені на сучасному етапі розвитку мови. Стрижневий компонент синтаксичного фразеологізму типово становить поєднання кількох лексем - службових і повнозначних слів, яким властиве семантичне спустошення або семантичний зсув» (Ситар, “Синтаксичні фразеологізми в українській мові” 2; див. також Величко; Всеволодова, Лим Су; Иомдин).

Пропоноване дослідження фразеологізованих речень виконано на матеріалі корпусу текстів Богдана Лепкого, доступного за адресою http://corpora.donnu.edu.ua/bonito/run.cgi/corp_info?corpname=kitaeva. Цей корпус текстів створено Вікою Кітаєвою під керівництвом Іллі Данилюка. Технічну реалізацію проєкту здійснено за допомогою вільного корпусного менеджера NoSketch Engine (https://www.sketchengine.eu/). Корпус текстів об'єднує лише прозові твори Богдана Лепкого, містить 893681 токенів, 681516 слів, 76237 речень, 7 документів. За стратегією побудови і призначенням цей корпус текстів $\epsilon$ дослідницьким; за типом репрезентації текстів - повнотекстовим; усі тексти $є$ письмовими (зразків усного мовлення не залучено через їх відсутність); корпус $\epsilon$ динамічним, тобто $є$ можливість його поповнення. Докладно про типи корпусів текстів див. працю Орисі Демської-Кульчицької (Демська-Кульчицька).

Мета цього дослідження - виявити особливості реалізації моделей фразеологізованих речень у творах Богдана Лепкого. Поставлена мета передбачає виконання таких завдань: а) виділити всі моделі фразеологізованих речень, ужиті 
в корпусі текстів Богдана Лепкого; б) визначити їх семантику; в) установити абсолютну частоту в корпусі текстів, відмежувавши їх від омонімічних нефразеологізованих речень; г) виділити функції, реалізовані фразеологізованими реченнями у проаналізованих текстах.

Термін «модель речення» використовуємо в розумінні Майї Всеволодової. У межах запропонованої дослідницею функційно-комунікативної теорії синтаксису модель речення визначено як нерозривну єдність форми речення, відтвореної у вигляді структурної схеми, і типового значення речення (Всеволодова, 336 і далі).

Об'єктом дослідження є фразеологізовані речення, виявлені в корпусі текстів Богдана Лепкого; предметом - структурні, семантичні і прагматичні властивості цих речень.

Опис фактичного матеріалу та методів, застосованих у процесі аналізу. Фактичним матеріалом дослідження стали 177 фразеологізованих речень, дібраних з корпусу текстів Богдана Лепкого.

Для аналізу мовного матеріалу використано такі методи: моделювання (для побудови структурної схеми речення, що відбиває особливості формальної організації синтаксичних фразеологізмів); описовий метод (для забезпечення опису структурних і прагматичних ознак фразеологізованих речень); структурний метод, який втілено в прийомі дистрибутивного аналізу - для виявлення особливостей фразеологізованих речень у різних контекстах, формулювання типового значення моделі речення.

Наукова новизна дослідження зумовлена тим, що фразеологізовані речення у творах Богдана Лепкого досліджено вперше.

Теоретична цінність отриманих результатів щодо особливостей мови Богдана Лепкого полягає в тому, що здійснений аналіз підтверджує висновки про унікальність набору фразеологізованих речень у кожної лінгвоперсони, одержані в дослідженнях (Ситар “Синтаксичні фразеологізми в лінгвоперсонологійному портреті Михайла Коцюбинського”; Ситар "Синтаксичні фразеологізми як складник лінгвоперсонологійного портрету Юрія Шевельова”; Ситар “Реалізація моделей”), а також дає змогу простежити комунікативні прийоми впливу мовних одиниць на читача або слухача.

Практична цінність одержаних результатів умотивована тим, що вони можуть бути використані для встановлення авторства тексту, у лексикографічній практиці, під час викладання у вищій школі курсів з лінгвістичного моделювання, фразеології, синтаксису й семантики.

Виклад основного матеріалу й обгрунтування результатів дослідження. Фразеологізовані речення є «важливим елементом мовлення будь-якої особистості, проте і вибір моделей, і активність їхнього вживання є суто індивідуальними в кожному випадку» (Ситар “Синтаксичні фразеологізми в лінгвоперсонологійному портреті Михайла Коцюбинського” 176). 3 корпусу текстів Богдана Лепкого вилучено 177 фразеологізованих речень, що виявилися реалізаціями 18 моделей (зі 105 моделей українських синтаксичних фразеологізмів української мови, описаних у праці (Ситар, “Синтаксичні фразеологізми в розрізі кон- 
струкційної граматики”)).

1. Модель, побудована за структурною схемою2 Де $\mathrm{N}_{3} \operatorname{Inf} / \partial o \mathrm{~N}_{2}$, має заперечне або заперечно-модальне значення: Орлик навшпиньках виходить зі світлиці і кличе післания за собою.

- Хірурга! Скоро до гетьмана хірурга, хай негайно іде з п'явками і банками, з блюментростовою мастю! - дає прикази в сінях, а до післания говорить:

- Не дадуть чоловікові спокійно вмерти. Де йому до коня, до команди? Куди, куди! Це ж живий труп.

- Його величество не знав, щзо з Іваном Степановичем так погано. Доповідали, щэо ие проходячії болі, щэо він так изілі роки хорує (Богдан Лепкий. Не вбивай).

Важливою особливістю реалізації цієї моделі в Богдана Лепкого є введення інфінітива в позиції змінного компонента із заповненням суб'єктної синтаксеми іменником або займенником у формі давального відмінка: $A$ я:

- А иі коміроцьки хто повироблював, ви? Обоє в сміх:

- Куди нам до такої роботи!

— Це пчоли такі майстри, — повчає нас Кость. - А знаєте, чому иі комірки шестигранні? Де вам це знати! Тому, бо в них мід добре держиться й не розсаджує стінок. Це дуже трівка посуда (Богдан Лепкий. Казка мого життя) (= Ви цього не знаєте; = Ви не можете цього знати);

«Бути за гетьмана стародубському полковникові! Івана Ілліча Скоропадського вибираймо!» — залунало кругом. Аж і вийшов на поміст стародубський полковник, поклонився громаді і каже: "Дякую вам за велику честь, панове товариство, над яку більшої і бути не може, але я чоловік старий, де мені гетьманувати! До такого важного і важкого уряду треба людини заслуженої і не старої. Виберіть чернігівського полковника Полуботка» (Богдан Лепкий. Полтава) (= Я не можу гетьманувати).

Ця модель у корпусі текстів має абсолютну частоту 6.

2. Одиничним прикладом репрезентовано модель До чого $\mathrm{N}_{1} \mathrm{Cop}_{\mathrm{f}} \mathrm{Adj}_{1}$, що має значення позитивної оцінки мовцем реалії: Співали Денисівиі пісні Вєрбицького, Лаврівського й Воробкевича, але співали їх так по мистецьки, з таким відчуттям музичного змісту, з так знаменито вистудіованою динамікою, так були зіспівані, щуо хор їх звучав, як якийсь зачарований інструмент. Та ще співали вони без нот і на естраду виходили гарно й справно. Не було зайвих павз, ні нудного роздавання голосів. Один помах руки провідника і неслася пісня несилувана, пригодна «Не хочеться вірити - казали поляки - щоби це хлопи співали. Дивіться, до чого спосібний цей нарід!» (Богдан Лепкий. Казка мого життя).

3. Фразеологізована модель речення Kyдu $\operatorname{Pron}_{3} \operatorname{Inf} /$ дo $\mathrm{N}_{2}$ використовувана 3 модально-заперечним значенням (абсолютна частота - 2): Розстрига, замість репліки, вишкірив свої рідкі зуби:

${ }^{2}$ У структурній схемі речення використовуємо такі позначки: $\mathrm{Adj}$ - прикметник; $\operatorname{Adv}_{\text {praed }}$-прислівник у ролі предиката; Сорғ - відмінюване дієслово-зв'язка; Inf - інфінітив; $\mathrm{N}_{1}$ - іменник у називному відмінку; prep прийменник; Pron $_{3}$ - займенник у давальному відмінку; $\mathrm{V}_{\mathrm{f}}$ - відмінюване дієслово; $\mathrm{V}_{\mathrm{f3s} / \mathrm{pl}}-$ відмінюване дієслово у формі 3-ої особи однини або множини; $\mathrm{V}_{\mathrm{imp}}$ - відмінюване дієслово у формі наказового способу; ( ) факультативність компонента; / - варіантність компонента. 
- Гарно сказане, їй-Богу, гарно, аж оскома пішла. I куди мені до того! Куди! Сухо в жмені, а пусто в кишені, куди не йду, бідуведу, горем поганяю (Богдан Лепкий. Не вбивай).

Цікаво, що в корпусі текстів зафіксовано лише варіант $К y \partial u \operatorname{Pron}_{3} \partial o \mathrm{~N}_{2}$, водночас теоретично можливий інфінітивний варіант моделі лишився нереалізованим, пор.: Куди мені встигнути! Куди мені гетьманувати!

4. Речення, побудовані за структурною схемою Куди там $\mathrm{N}_{1} / \mathrm{V}_{\mathrm{f}} / \mathrm{Inf} / \partial o / 3$ $\mathrm{N}_{2}$, передають у прозових текстах Богдана Лепкого декілька значень:

а) відсутності реалії або ситуації: Кажуть, давно не було такого врожаю, - додала Марія Федорівна. - Де кум, де коровай. Куди там жннива, тітусю! Ще й весняні бурі не прошуміли (Богдан Лепкий. Не вбивай) (= Не було ще жнив);

б) неможливості виконання дії:

- Сто тисяч осьмачків борошна! - кивалася, як жид на шабасі, хазяйка. - Легко сказати, мої ви, та нелегко добути. А ще тепер. Тепер хіба псів гнати, а не худобу. І як тут крізь такі сніги з набором пробиратися? - Правда ваша, - озвався той, щзо в кості щасливо грав. - Куди там тепер транспорти доставляти. Ось Ромни ніби якийсь город числиться, а глядіть, сніги на вулииях по пояс лежать (Богдан Лепкий. Полтава) (= Не можна доставити транспорт через сніг);

в) заперечення існування реалії або ситуації:

Злі люди монастир зграбували. Ні иеркви святої, ні келій наших не пощадили, а щу вже з черничками творили, не доведи Господи! Насилу я вирвалася з їх рук і втікаю.

- Не з добра побігла з двора, — пожалував гостю Улас.

- Ой куди там з добра! В монастирі рай, а на світі пекло, один великий гріх! Ні сорому, ні совісті, ні милосердя нині люди не мають, — нарікала. - Кiнець світа наближається (Богдан Лепкий. Крутіж) (= Ой не з добра).

Характерним для Богдана Лепкого $є$ прийменниково-іменниковий комплекс у позиції змінного компонента моделі (пор. для Михайла Коцюбинського властива лише інфінітивна реалізація цієї моделі - Куди там Inf (Ситар "Синтаксичні фразеологізми в лінгвоперсонологійному портреті Михайла Коцюбинського"): Ось яка різниия! Земля і небо! I всього за 5 літ така переміна! А нині? Куди там нині до минулого! Нині Василь Кочубей перзона, перма по гетьмані. По гетьмані!? I доки йому давати себе затемнювати тій гетьманській фігурі. Пора наперед, пора! (Богдан Лепкий. Мотря) (= Теперішнє не можна порівняти 3 минулим).

Конструкція куди там зафіксована в корпусі текстів Богдана Лепкого 5 разів.

5. Модель, побудована за структурною схемою Не до $\mathrm{N}_{2} \mathrm{Cop}_{\mathrm{f}}\left(\mathrm{N}_{3}\right)$, передає модально-заперечне значення небажання або неможливості дії або стану для суб'єкта:

- Службове діло, Іване Степановичу. Приказ, це приказ, хоч не до ӥзди мені (Богдан Лепкий. Мотря); 
- Добра мені верба, Кочубеєва Мотря! Це ж найпишніша троянда, панетоваришу! - завважив Орлик.

- Для тебе, генеральний писаре, бо ти, хоч свою гарну жінку маєш, але й на других не від того, щоб глипнути оком. Звичайно, - молодий. А мені вже не до жсінок (Богдан Лепкий. Не вбивай).

Факультативним компонентом моделі є суб'єктна синтаксема у формі давального відмінка $\left(\mathrm{N}_{3}\right)$, що в Богдана Лепкого в усіх зафіксованих випадках заповнена, тобто для нього є важливим є назвати суб'єкта небажаної / неможливої дії або стану:

— Так що? Втікла від батьків, покине й чоловіка. Любов найгірша страсть. - Любов найгірша страсть, — зітхав той, щзо в небо дивився.

- Гетьманові тепер не до того. - Усім нам не до кохання. - Наше кохання - війна (Богдан Лепкий. Полтава).

Модель Не до $\mathrm{N}_{2} \mathrm{Cop}_{\mathrm{f}}\left(\mathrm{N}_{3}\right)$ належить до продуктивних (абсолютна частота вживання - 20). Загалом же конструкцію не до вжито в корпусі текстів 81 раз, проте 61 випадок не залучено до аналізу, оскільки ці речення є вільними (нефразеологізованими): Розійшлась чутка, щэо гетьман не до ияаря, а до шведа поӥхав (Богдан Лепкий. Батурин).

6. Фразеологізована модель, що відповідає структурній схемі Ось $\left(\mathrm{N}_{3}\right) \mathrm{N}_{1} \mathrm{Cop}_{\mathrm{f}}$, вживається на позначення негативної оцінки мовцем реалії або ситуації загалом (абсолютна частота в корпусі текстів - 3): «Ось вам народ! - каже до Обидовської Мручко. - Інший то навіть умерти без жартів не вміє. Дивний народ і дивна його доля.» (Богдан Лепкий. 3-під Полтави до Бендер).

7. Таке ж типове значення має і модель $O c b \mathrm{~N}_{3} i \mathrm{~N}_{1}$ Сор $_{\mathrm{f}}$ : Гетьман не слухав тієї розмови. Його збентежила несподівана гостина. Ось тобі і гостя! Хоч клич Петранівського, щоб стріляв до неї. Ти ії слово, а вона тобі два, ти ії колючкою, а вона тобі ножем поміж ребра. Ось таку з полком у найгірший вогонь послати. Мабуть, і Петра налякала б (Богдан Лепкий. Мотря). Абсолютна частота вживання цієї моделі -2 .

8. Негативно оцінне значення властиве фразеологізованій моделі Ось який $\mathrm{N}_{1} / \operatorname{Adj} \mathrm{Cop}_{\mathrm{f}}$, ужитій в текстах письменника 4 рази:

- А за що ж тебе, чоловіче добрий, з академії прогнали?

- За жінку.

- Ага. А за чию?

- Та за дякову. За малинську дячиху.

— Ось який ти! - Та я такий, як і інші: не гірший і не кращий, лиш вона чортова баба.

- Розумію: побили Хому за Яремину вину.

- Щось наче б так. Вередлива була. I те їй давай, і друге принеси, хоч із коліна вилупи, а щоб було.

- Розумію. Та вона тебе, значить, на слизьке загнала... (Богдан Лепкий. Крутіж).

Цікаво, що тип оцінки може бути експлікований у найближчому контексті: - А як тебе, братчику, звати? 
- Антоном мене клич, а величай Помелом. А тебе?

- Босим.

- Босим?

- Краще Босим жити, ніж Босаковським гнити. Ось які тепер часи.

- Дійсно, погані часи, пане Босий.

- Погані, добродію Помело, погані.

- Одна потіха, що люди завжди на лихі часи нарікали.

- Мала потіха. Дальші слова собаки заглушили (Богдан Лепкий. Крутіж).

9. Модель, побудована за структурною схемою $O m$ i/ŭ $\left(\mathrm{N}_{3}\right) \mathrm{V}_{\mathrm{f}} / \mathrm{N}_{1}(\mathrm{Adj}) \mathrm{Cop}_{\mathrm{f}}$, передає негативно оцінне значення, iї зафіксовано в корпусі текстів 14 разів: Осавул переїхав $i$ зсів з коня. Господар, старий запорожечь Верига, приглядаючись, поклав свою важку руку йому на рам'я: “От і часи, брате, бодай не діждали!» (Богдан Лепкий. 3-під Полтави до Бендер). Особливістю цієї моделі $\epsilon$ варіативність морфологічного наповнення змінного компонента:

- Дякую вам, Мотре Василівна, за комплімент. Але найкращий паж не рівня королеві.

- Гарний король і найкраму королеву затьмить, - відповіла не надумуючись Мотря.

— От і попали, дядьку! Гетьман удавав, щуо відповісти не вміс.

- Мотря Василівна слів позичати не потребують.

- Не все. Часом і слово, як з каменя, важко добути (Богдан Лепкий. Мотря);

- От і час який непевний. То мороз, то відлига. Ніби сам Бог хоче, щоб люди у хаті сиділи (Богдан Лепкий. Полтава).

10. Одиничним прикладом у проаналізованих текстах репрезентовано модель зі значенням негативної оцінки і структурною схемою $O m\left(\mathrm{~N}_{3}\right) \mathrm{N}_{1} \mathrm{Cop}_{\mathrm{f}}: T a$ тові подавала руку, з мамою цілувалася палко, а тоді підносила хлопия й казала: «От мені козак! Навіть за тілетку пшениці не важить...» (Богдан Лепкий. Казка мого життя).

11. Фразеологізована модель От який $\mathrm{N}_{1} / \operatorname{Adj}_{\text {Cop }}$ вжито двічі з різними значеннями:

а) заперечення існування реалії: Так нас тії москалі обсіли, щяо обігнатися годі. Гетьманові прожитку не дають. Все якісь посли то від иаря, то від Меншикова: гетьман хвилюється, та нічого не вдіє. Мусить робити що йому велять. Oт яка тут воля! (Богдан Лепкий. Не вбивай).

б) негативної оцінки: А скінчиться війна, так гонять тебе з полку, як собаку з хрестин. Ти хто такий? Хахло, тягло, хамська твоя мати, йди на панів працювати. От яка наша правда, браття (Богдан Лепкий. Батурин).

12. Модель, побудована за структурною схемою Такий (уже/вже) $\mathrm{N}_{1} / \mathrm{Adj}$ $\mathrm{Cop}_{f}$, має типове значення позитивної або негативної оцінки реалії або ситуації. Тип оцінки в цій та інших оцінних моделях визначуваний передусім контекстом або лексичним наповненням стрижневого компонента моделі: «Поїхав наш король,» - сумно говорили шведи. «Поїхав ... Бог вість, чи побачимо його.» «Чому б ні. I завтра буде день.» «Так, але король недужий. Погано з його ногою. Ліки 
не помагають.» «Бо такі ліки. Щоб він лиш до Швеції вернувся, побачите, видужає скоро.» (Богдан Лепкий. 3-під Полтави до Бендер) (негативна оцінка);

- Така вже моя вдача. Ти бачиш, яка я. Все люблю робити наперекір другим і собі (Богдан Лепкий. Мотря) (негативна оцінка);

- Меншиков? - Мабуть, послухає, бо не перечив.

- Жаль чоловіка. Такий інтелігентний. - Його хоч би й на герцога, то не сором. Жаль (Богдан Лепкий. Батурин) (позитивна оцінка).

Абсолютна частота вживання речень, що належать до цієї моделі, - 12 .

13. Фразеологізовані речення, побудовані за структурною схемою $X m o$, як не $\mathrm{N}_{1} \mathrm{~V}_{\mathrm{f}} / \mathrm{Adj} \mathrm{Cop}_{\mathrm{f}}$, спеціалізовані на семантиці акцентування: Так то вони довго радили і журилися, аж стало на тім, що нікому їхати в Батурин, лиш одній ігумені. Вона, як священна особа, найкраще надається на посла такої нещасливої новини. Хто, як не ігуменя, може розважити тяжко опечалених родителів у їх великому горю, кому більше, як не їй, безпечно тепер їхати в Батурин? (Богдан Лепкий. Мотря). У проаналізованому матеріалі речення, що належать до цієї моделі, вжито тричі. Варто наголосити на зміненому порядку слів у реченнях, що належать до цієї моделі (2 із 3 прикладів), що є властивим лише окремим фразеологізованим моделям: Треба ж раз опанувати степ і упорядкувати руїну! А хто жк має зробити початок, як не гетьман? За ним підуть полковники, старшини, сіль землі, а там і народ розживеться, засмакує в мирі, добробуті, в свободі та навчиться обороняти їх кріпко й мудро, повсякчасно, а не зривами хвилевими, як розбурхана стихія (Богдан Лепкий. Полтава);

Геракл - ие міт, а ми реальні люди, нам і над утомою запанувати треба. Вчинки вашої милості переходять межі реального.

- Це щуо лиш будучність покаже.

- Будучністю сильні люди правлять.

- Від найсильніших невідоме сильніше. I король прислонив очі рукою. - Чи не зробив я похибки в синтаксі? - спитав, зміняючи голос.

- Наскільки я латинську мову знаю, ні.

- Чоловік ніколи не є певний слова... Ані діла, - додав, подумавши хвилину.

- Хто же тоді може бути певний, як не милість ваша?

Король заперечив головою

- Нi, ні. Я ше менше, ніж другі... У непевності весь чар життя. Бути певним - значить капітулювати перед самим собою. Життя - че гра, а в грі певності немає. Певний грач - шулер (Богдан Лепкий. Полтава).

14. Одиничну реалізацію в текстах Богдана Лепкого має фразеологізована модель Чому $\sigma\left(\mathrm{N}_{3}\right)$ не Inf з модальним значенням бажання: Туркені з серпанками на лииях ішли, майже не доторкаючись землі своӥми гостроносими виступиями без закаблуків. Ритмічно широкими бедрами колисали. «Також спосіб заслонювати обличчя, - сердився Понятовський. - Може, котра й гарна, так чому б не глянути. Не вкушу. По очах знати, що палкі. Як ви думаєте?» - торкнув ліктем Клінковитрема (Богдан Лепкий. Крутіж) (= Я хочу подивитись на обличчя туркень). 
15. До продуктивних моделей (абсолютна частота 17) зараховуємо фразеологізовані речення, побудовані за структурною схемою Що (ж/ųе/то) за $\mathrm{N}_{1} \mathrm{Cop}_{\text {f. }}$ Такі речення виражають позитивну або негативну оцінку реалії мовцем:

- Го-го-го! - гукнув Кочубей. - Кого я бачу, щчо за гість! Чуйкевич обняв його за ноги, а Кочубей пригорнув козака до себе і тримав його довгу хвилину біля грудей, зазначуючи таким чином свою прихильність до нього (Богдан Лепкий. Мотря) (позитивна оцінка);

«Що за народ! - покивав головою Мручко. - Гадав би ти, саме завзяття, сама лютість, а він тобі навіть до конини так пристраститься, щуо й життя не пожалує» (Богдан Лепкий. 3-під Полтави до Бендер) (негативна оцінка).

Поєднання щзо за вжито в корпусі текстів 122 рази, проте більшість випадків (110) становлять нефразеологізовані підрядні речення з'ясувального, атрибутивного та інших типів: Хіба ти не чув, ще за столом казали? (Богдан Лепкий. Батурин); А в батуриниів мало гармат і бракло того, кого вони слухати привикли, не стало Кенігзена, що за десятьох працював, а за сотки розумів гарматне діло (Там само).

Факультативним компонентом цієї моделі виступають частки ж, це, то:

- Боже, щцо то за чоловік був, а що за проводир! Сама сила й розум. Уже такого другого в Украйні не буде. Куди, куди!

- Не буде, - притакнув, зітхаючи другий.

- Ой, не буде! - доповів третій і почав проказувати думу про жовтоводську битву (Богдан Лепкий. Крутіж) (позитивна оцінка).

16. Фразеологізована модель речення Як (же/mym) $\left(\mathrm{N}_{3}\right)$ не Inf / $\mathrm{Adv}_{\text {praed }} \mathrm{y}$ текстах письменника вживається 21 раз з такими значеннями:

а) ствердження / згоди із думкою співрозмовника: Мама відповіла, щзо тато ще лишилися в Крегульиі, щуоб продати збіжжя та «спакувати меблі». За тиждень будуть готові. «То ми вишлемо намі вози, щоб їх перепровадити, правда, пане начальнику?» - звернувся до війта, що за той час надійшов. Коротка свитка. «А вже ж, щзо вишлемо. Як не вислати?" - відповів начальник громади, старий, маломовний господар (Богдан Лепкий. Казка мого життя).

б) потрібності виконання дії або виникнення стану:

- Невже ж я вас насильно перевіз за Десну? Не обіиялися ви витривати при мені, добуваючи батьківщині нашій слави й волі? Як же вам не сором являтися перед шведом такими, як ви є, горлаями, бешкетниками, п'яницями. Дивіться, вони із заморських країв прибули, роками цілими терплять горе й злидні походного життя і не бунтуються. А ви днів кілька, як зі свойх стоянок вийшли, і шумите. Погано ви собі починаєте, панове товариство, погано! Не тільки мою сиву голову зневажаєте, але й своє ім'я козаџьке. Батьки вамі у гробах перевертаються, бачучи безтяменність вашу. Дальше так годі (Богдан Лепкий. Полтава) (= Вам має бути соромно);

в) неможливості невиконання дії:

- Чого смієшся з мене?

- Як не сміятися, коли ти щось такого смішного скажеш?... (Богдан Лепкий. Казка мого життя) (= Я не можу не сміятися). 
У зібраному матеріалі переважає інфінітивний варіант моделі Як (же/тут) $\left(\mathrm{N}_{3}\right)$ не $\operatorname{Inf}(17$ із 18 реалізацій).

17. Найпродуктивнішою в текстах Богдана Лепкого виявилась фразеологізована модель Який (уже/вже/же/ж) $\mathrm{N}_{1} \mathrm{Cop}_{\mathrm{f}}$, що передає три значення:

а) негативну або позитивну оцінку мовцем реалії або ситуації загалом:

- Але ми балакаємо, - почав господар, — а ваша милість утомлені. Який жсе я нездара. Жінко! А приладь там постіль у світлиці і дай чистої води в циинову вмивальнищю, та ще добудь із скрині білля щонайтоншого, спішись (Богдан Лепкий. Батурин) (негативна оцінка, в обстеженому матеріалі цей тип оцінки переважає);

Мотря знов очі спустила вдолину. - Гей-гей! - казала, - які ж бо ви, хлопиі, дурні, які дурні! Яка-будь юбка - і серие загориться, як губка. Коли б я хлопием була, то за мною гинули б дівчата. - Певно. - Авжеж, щьо певно, бо я їх брала б не плачем, а мечем, я би їх, як пожежа, палила, як гураган, мела! Кинула роботу геть, стала $i$, затискаючи долоні, говорила: - Ах, яка розкіш бути сильною, великою, грізною, яка розкіш! Як я такої розкоші бажаю (Богдан Лепкий. Мотря) (позитивна оцінка);

б) заперечення існування реалії або ситуації (у поєднанні з негативною оцінкою):

- Найкраще пошукала б собі доброго чоловіка. Гадаю, що знайти не важко. І врода є, і гараздів Бог не поскупив.

- Лишім це, тату. Судженого і конем не об'їдеш.

- Суджене не розгуджене, - притакнув Кочубей, а подумавщи хвилину, спитав:

- А на свята не пойхала б додому? У мене сани з будою, коні скорі, дорога недалека. Сумно мені буде стрічати Різдво без тебе. Знаєш, я сім'янин - які мені свята без моӥх дітей? (Богдан Лепкий. Мотря) (= Нема свята без дітей; Погане свято без дітей));

в) вказівка на великі / малі параметри реалії в поєднанні з ії оцінкою (параметрично-оцінне значення):

- Свдокія Івановна, - рекомендував полковник Войнаровському засоромлену молодиџю. - Що я кажу, не Івановна, а - як твоє отчество, Явдошка?

- Гаврилівна, — відповіла і кокетерно ліве лице рукою прислонила.

- Свдокія Гаврилівна, честь маю відрекомендувати, прошу милувати ї, женщина первостепенних чеснот. Одно те, як гуляє. Фу, чорт, як вона тобі гуляє! Пропадай, пропадай, лииарськеє серие! Ноги які, а бюст. Гляньте на й бюст! (Богдан Лепкий. Батурин);

—Господи! Який же він високий!.. Ще трохи і головою об стелю гепне. Також якийсь чорт вигадав тії кості! - нарікає. - Ані то шабля, ані то дівка, а манить. Яка тепер довга ніч, а цілу за ними пересидиш, де який гріш маєш, висотають і пустять тебе, як туреиького святия (Богдан Лепкий. Полтава).

Висока абсолютна частота вживання (46) може бути пояснена багатозначністю моделі, родовою і числовою варіантністю (який/яка/яке/які) змінного компонента моделі і можливістю введення часток (який же, яка вже і под.). 
18. Фразеологізовані речення, побудовані за структурною схемою Який там $\mathrm{N}_{1} \mathrm{Cop}_{\mathrm{f}}$, ужито в корпусі текстів 17 разів у таких значеннях:

a) заперечення існування реалії / ситуації або незгоди з думкою іншого мовця (ці відтінки значення у проаналізованому матеріалі складно диференціювати):

Знали, шуо Август відрікся там королівської корони, від Чуйкевича довідалися, щуо, крім того, написав власноручне письмо до Лещуинського (розуміється, на бажання Карла), в котрім поздоровляв його як нового, законного короля. Та ще зірвав Август союз із Петром і дав Кардові слово, щу заплатить контрибуцію, не буде нападати на шведів і проти них не буде з ніким шукати ворожих союзів. - А чи додержить слова? - спитала Мотря, котрої прихильність була по стороні короля Станіслава. Чуйкевич похитав головою. - Яке там у політиці слово. Роблять те, щуо мусять. Август дає слово, а його сторонники в Любліні зговорюються з Петром (Богдан Лепкий. Не вбивай) (= Нi, не дотримає слова. У політиці не дотримують слова);

- Я не дитина, тату.

- В батька й мами ти все дитина, донька.

- В мами - ні, бо мама мене не любить, ненавидить мене. - За те, щуо ти непокірлива, Мотре! - В маму вдалася. Кочубей глянув на доньку. - Але ж ти донька, а вона мама, не їй поступатися, а тобі, так $і$ закон велить, шуоб діти слухали родителів своӥх.

- Не в питаннях серияя.

- Яке там серце, Мотре? Гетьманові на сьомий хрестик іде (Богдан Лепкий. Мотря) (= Не про серце йдеться);

б) неможливості виконання дії або перебування в певному стані:

- А нам пора. Простіть, щуо позбавили сну.

- Який там сон тепер. Спасибі, щуо зайшли. Бувайте! (Богдан Лепкий. Батурин) (= Ми не можемо тепер спати).

Здійснений аналіз мовного матеріалу засвідчує, що вживання в мовленні фразеологізованих речень завжди є підпорядкованим певній меті. Серед 8 прагматичних функцій (Ситар “Синтаксичні фразеологізми в розрізі конструкційної граматики”) у текстах Богдана Лепкого реалізовано лише 4, але переважно вони поєднуються:

а) експресивна функція, що втілює здатність синтаксичного фразеологізму передавати суб'єктивне ставлення мовця до ситуації загалом або до іiі учасника (учасників):

- А ти, славити Бога, живий. Що - живий! Я тебе щуе й оженю. Побачиш, щзо оженю! - і Босаковський з такою силою поклепав старого по плечах, щуо той аж перевернувся.

— От тобі й жених! - сміявся Босаковський. - Що ж буде, як тебе жінка за чуба вхопить, бо я тобі у свойх «майонтках» таку жіночку підшукати гадаю, щзо прямо хоч у коноплі став. Тебе і ї̈ (Богдан Лепкий. Крутіж);

б) фатична функція:

- Аж і зашушукали люди: відьма! Не знати від кого воно пішло, коли й чому, досить щзо: відьма, відьма, відьма!.. I погадайте: не поміг муж-полковник, не 
помогли багатства, нічого не помогло. Настягали всілякого патиччя на майдан, склали костер і тягнуть відьму палити. I згоріла би, коли б не протопіп. У ризах церковних з хрестом у руках вийшов і ледве тим хрестом пожар угасив і полковницю від соромної смерті ізбавив ... У черниці пішла ... Ось вам і щастя, кінчив оповідання дід: такту);

- На високому щееблі стояла, а черницею вмерла (функція завершення кон-

в) коректувальна функція, утілена в їі заперечному варіанті (мовець уживає фразеологізоване речення для заперечення думки співрозмовника):

- Не своя була з самого ранку.

- Хто тобі ие сказав?

- Сестра твоя, Марія Федорівна.

- Знайшов церквоньку Богу ся молити. Моя сестра теж дев'ятої клепки не має. Вона теж на старого гетьмана дивиться як на Бога. Гадає, Сомкова душа вселилася в нього. Це якісь біснуваті жінки, і моя сестра, і твоя донька.

- А твоя - ні?

— Твоя, бо ти ї̈ від малої дитини розвіз, як цииганську фанду, а тепер кому клопіт? Мені.

— Який там клопіт? Віддамо за надійного чоловіка, $і$ клопотам кінеиь.

- Волами ї̈ до престола потягнеш, - ая! Побачиш. Я вже знаю. Я вже все розумію. Я не така короткозора, як ти, щьо дивишся і не бачиш, ніби заяџь, з незамкненими очима спиш.

— Ну, ну, який там я тобі заяць? Добрий мені заяџь - генеральний суддя! - Ха, ха, ха! Генеральний суддя. Що таке генеральний суддя? - Перший по гетьмані чоловік на Україні... от щцо! (Богдан Лепкий. Мотря);

г) аргументативна функція, за якої синтаксичний фразеологізм наводиться для переконання у правильності думки / дії мовця: «А цар що?» - спитав, усміхаючись, гетьман. "Сильно розсердився на блазня, бо чареві можна все нехтувати, тільки нової столиці не торкай. «Тікай до чорта, - гукнув, - i по моїи землі ходить не смій, а то вб'ю, як собаку.» «I Балакірев пімов?» «Як не піти, коли цар проганяє? Декілька днів не показувався изареві на очі. Аж нараз, гляди, їде собі повозкою, а жінка біля нього, як коли б ніщо. Цар зупиняє його. «Як ти смієш? Я ж тобі заборонив ходити по мой землі...» - «Це не я ходжу, а коні, каже Балакірев, - яна фінській землі стою.» Дивиться иар, а в Балакірева дійсно під ногами мімок якоїсь землі, а на йому фінська урядова печать (Богдан Лепкий. 3-під Полтави до Бендер) (= Він повинен піти).

За нашими спостереженнями, важливою ознакою мовлення Богдана Лепкого $є$ нанизування моделей фразеологізованих речень, що забезпечує експресивність та емоційність мовлення персонажів творів, викликає потрібне враження в читачів (зафіксовано 9 контекстів). Таке нанизування може бути двох типів:

1) поєднання декількох реалізацій однієї моделі синтаксичного фразеологізму (6 прикладів): Орлик тривожно споглядав на двері... Коли ж відчиняться вони? I коли на порозі появиться дід, ростом ще вищий від царя, з очима, поли- 
нялими від сония, в сорочиі, на дощах праній, на вітрах сущеній, з великою незгійною раною на грудi?.. Що за жаль, щьо за шум! Тільки й край, тільки дум, стільки в народі сили, а кругом лиш могили і кінця їм немає. Слава воскресення чекає, від Воскресення до Вознесення з року на рік, весь вік, і нема нам спасення (Богдан Лепкий. Полтава);

2) нанизування синтаксичних фразеологізмів, що належать до різних моделей (3 контексти): Осавул переїхав і зсів з коня. Господар, старий запорожець Верига, приглядаючись, поклав свою важку руку йому на рам'я: «Om $\boldsymbol{i} \boldsymbol{u a c u ,}$ брате, бодай не діждали!» ... «Вже знаєте?» - спитав осавул. «Як не знати! Люди з хуторів утікають, гетьман з королем на Очаків подалися. Гірка їх доля! (Богдан Лепкий. 3-під Полтави до Бендер).

Висновки та перспективи дослідження. Фразеологізовані речення в текстах Богдана Лепкого є яскравими засобами експресивного синтаксису, за допомогою яких він передає оцінне, модальне, заперечне (модально-заперечне) значення або значення акцентування. Письменник використовує 18 моделей синтаксичних фразеологізмів, 3-поміж яких найбільш продуктивними виявилися Який (уже/вже/же/ж) $\mathrm{N}_{1} \mathrm{Cop}_{\mathrm{f}}$, Як (же/тут) $\left(\mathrm{N}_{3}\right)$ не Inf / $\mathrm{Adv}_{\text {praed }}$, Не до $\mathrm{N}_{2} \mathrm{Cop}_{\mathrm{f}}$ $\left(\mathrm{N}_{3}\right)$, Що (ж/це/то) за $\mathrm{N}_{1}$ Сор $\mathrm{i}$ Який там $\mathrm{N}_{1}$ Сор $_{\mathrm{f}}$ Одиничними прикладами репрезентовано моделі До чого $\mathrm{N}_{1} \operatorname{Cop}_{\mathrm{f}} \mathrm{Adj}_{1}, O m\left(\mathrm{~N}_{3}\right) \mathrm{N}_{1} \operatorname{Cop}_{\mathrm{f}}$ i Чому $б\left(\mathrm{~N}_{3}\right)$ не Inf. За кількістю складників переважають моделі з двочленним стрижневим компонентом, за частиномовним статусом стрижневого компонента - моделі зі складеними частками.

Серед 8 прагматичних функцій синтаксичних фразеологізмів у прозових текстах Богдана Лепкого реалізовано лише 4: експресивну, фатичну, коректувальну й аргументативну.

Різнотипність за морфологічним наповненням, кількістю складників у межах стрижневого компонента, втіленою семантикою і функціями синтаксичних фразеологізмів є свідченням багатства синтаксису Богдана Лепкого, зв'язку 3 розмовним народним мовленням. Водночас вибірковість уживання фразеологізованих речень (18 із 105 можливих) дає змогу зарахувати їх до синтаксичних маркерів мовлення особистості.

Характерним для мовлення Богдана Лепкого виявилось нанизування фразеологізованих речень, побудованих за однією або різними структурними схемами.

Перспективи подальших досліджень полягають у виділенні інших ідентифікаторів мовлення особистості на синтаксичному рівні.

\section{Література}

1. Величко А. В. Синтаксическая фразеология для русских и иностранцев: Учебное пособие. Москва: Изд-во Московского государственного университета им. М. В. Ломоносова, 1996. $96 \mathrm{c.}$

2. Всеволодова М. В. Теория функционально-коммуникативного синтаксиса. Фрагмент прикладной (педагогической) модели языка. Москва: УРСС, 2017. 656 с. 
3. Всеволодова М. В., Лим Су Ён. Принципы лингвистического описания синтаксических фразеологизмов: На материале синтаксических фразеологизмов со значением оценки. Москва: МАКС Пресс, 2002. 164 с.

4. Горох Г. В. Стилістичне використання художніх засобів мови у поетичних та прозових творах Богдана Лепкого. Наукові записки Тернопільського національного педагогічного університету імені Володимира Гнатюка: Літературознавство. 2012. № 36. С. 279-282.

5. Демська-Кульчицька О. Основи Національного корпусу української мови. Київ: Ін-т української мови, 2005. 218 с.

6. Діц В. Стилістичні функції пропріальної лексики в поезіях Богдана Лепкого. Мовознавчий вісник. Збірник наукових праць. Випуск 12-13. 2011. С. 260-263.

7. Загнітко А. П. Теорія лінгвоперсонології. Вінниця: Нілан-Лтд, 2017. 136 с.

8. Здіховська Т. В. Фразеологія прозових творів Уласа Самчука та Богдана Лепкого: монографія. Луцьк: Вежа-Друк, 2014. 200 с.

9. Здіховська Т. В. Фразеологія української прози першої половини ХХ ст. (на матеріалі творів У. Самчука та Б. Лепкого) : автореф. дис. ... канд. філол. наук. Луцьк, 2010. 20 с.

10. Здіховська Т. В., Горбач Н. В. Вигукові фразеологізми з емоційно-огцінним значенням у прозі Б. Лепкого та У. Самчука: семантичний і функційно-стилістичний аспекти. Наукові записки Національного університету «Острозька академія». Серія «Філологічна». 2017. Вип. 65. С. 116-119.

11. Здіховська Т. В. Функціонально-стилістичні та семантичні властивості фразеологізмів на позначення емоційних станів людини в прозі Богдана Лепкого. Науковий вісник СНУ імені Лесі Украӥнки. Луцьк: СНУ імені Лесі Українки, 2014. № 6 (283). Серія : Педагогічні науки. C. $79-83$.

12. Иомдин Л. Л. Большие проблемы малого синтаксиса. Труды международной конференции по компьютерной лингвистике и интеллектуальньм технологиям Диалог'2003. Москва: Наука, 2003. С. 216-222.

13. Кравченко-Дзондза О. Мовностилістичні особливості прози Б. Лепкого. Дивослово. 1999. № 8. C. 9-11.

14. Мішиньова Т. Функціонування фразеологізмів у трилогії Богдана Лепкого «Мазепа». Волинь філологічна: тексті контекст. Луцьк: Вежа, 2008. Вип. 6. Ч. 1. С. 458-483.

15. Свердан Т. Спосіб трансформації фразеологізмів (усічення) як стилістичний прийом у трилогії Б. Лепкого «Мазепа». Культура слова / НАН України, Ін-т української мови. Вип. 5556. 2000. C. 26-30.

16. Свердан Т. Усічені фразеологізми у трилогії Б. Лепкого «Мазепа». Дивослово. 1999. № 1. C. $14-17$.

17. Ситар Г. В. Синтаксичні фразеологізми в розрізі конструкційної граматики: монографія: [наук. і відп. ред. А. П. Загнітко]. Вінниця : ТОВ «Нілан-ЛТД», 2017. 458 с.

18. Ситар Г. В. Синтаксичні фразеологізми в українській мові: структурно-семантичний, прагматичний і прикладний виміри. Дисертація на здобуття наукового ступеня доктора філологічних наук за спеціальностями 10.02.01 «Українська мова» й 10.02.21 «Структурна, прикладна та математична лінгвістика». Донецький національний університет імені Василя Стуса, Київський національний університет імені Тараса Шевченка. Вінниця - Київ, 2017. $516 \mathrm{c}$.

19. Ситар Г. Синтаксичні фразеологізми в лінгвоперсонологійному портреті Михайла Коцюбинського. Теорія лінгвістичних парадигм: колективна монографія на пошану професора, член-кореспондента НАН України Анатолія Загнітка. Вінниця: ТОВ «Нілан-ЛТД», 2019. C. 172-195.

20. Ситар Г. Синтаксичні фразеологізми як складник лінгвоперсонологійного портрету Юрія Шевельова (на матеріалі корпусу текстів Юрія Шевельова). Лінгвістичні cmyдї̈/Linguistic Studies: зб. наук. праць. Вінниця: ДонНУ імені Василя Стуса, 2019. Вип. 37. С. 130134. 
21. Ситар Г. Реалізація моделей фразеологізованих речень у творах Ірен Роздобудько. Тhеоretical and empirical scientific research: concept and trends : Collection of scientific papers « ${ }^{\prime} О Г О \Sigma »$ with Proceedings of the International Scientific and Practical Conference (Vol. 3), July 24, 2020. Oxford, United Kingdom: Oxford Sciences Ltd. \&European Scientific Platform. P. 154-155.

22. Ткачук Т. І. Мовностилістична організація історичного прозового тексту (на матеріалі тетралогії Богдана Лепкого «Мазепа») : автореф. дис. ... канд. філол. наук. Київ, 2011. 20 с.

23. Фразеологізми у творах Богдана Лепкого : словник / гол. ред. С. Є. Панцьо. Тернопіль: Джура, 2010. 224 с.

\section{References}

1. Demska-Kulchytska, O. Osnovy Natsionalnoho Korpusu Ukrainskoi Movy (Fundamentals of the National Corpus of the Ukrainian Language). Kyiv: In-t ukrainskoi movy, 2005. Print.

2. Dits, Viktoriia. "Stylistychni Funktsii Proprialnoi Leksyky v Poeziiakh Bohdana Lepkoho (Stylistic Functions of Proprial Vocabulary in the Bohdan Lepkiy Creacion)." Movoznavchyi visnyk 12-13 (2011): 260-263. Print.

3. Frazeolohizmy u Tvorakh Bohdana Lepkoho (Idioms in the Works of Bohdan Lepkiy) : slovnyk / hol. red. S. Ye. Pantso. Ternopil: Dzhura, 2010. Print.

4. Horokh, H. V. "Stylistychne Vykorystannia Khudozhnikh Zasobiv Movy u Poetychnykh ta Prozovykh Tvorakh Bohdana Lepkoho (Stylistic Use of Artistic Means of Speech in Poetic and Prose Works of Bohdan Lepkiy)." Naukovi zapysky Ternopilskoho natsionalnoho pedahohichnoho universytetu imeni Volodymyra Hnatiuka (The Scientific Issues of Ternopil Volodymyr Hnatiuk National Pedagogical University): Literaturoznavstvo 36 (2012): 279-282. Print.

5. Iomdin, L. L. "Bol'shie Problemy Malogo Sintaksisa (Big Problems of Small Syntax)." Trudy mezhdunarodnoj konferencii po komp'yuternoj lingvistike i intellektual'nym tekhnologiyam Dialog'2003 (Proceedings of the international conference on computer linguistics and intellectual technologies Dialog'2003) (2003): 216-222. Print.

6. Kravchenko-Dzondza, Olena. "Movnostylistychni osoblyvosti prozy B. Lepkoho (Linguistic features of B. Lepkyy's prose)." Dyvoslovo 8 (1999): 9-11. Print.

7. Mishynova, Tetiana. "Funktsionuvannia Frazeolohizmiv u Trylohii Bohdana Lepkoho «Mazepa» (Functioning of Phraseological Units in Trilogy of B. Lepkoho «Mazepa»)." Volyn filolohichna: tekst i kontekst (Volyn phylologigal: text and context) 6(1) (2008): 458-483. Print.

8. Sverdan, T. "Sposib Transformatsii Frazeolohizmiv (Usichennia) yak Stylistychnyi Pryiom u Trylohii B. Lepkoho «Mazepa» (The Method of Transformation of Phraseology (Truncation) as a Stylistic Device in the Trilogy of B. Lepkyi «Mazepa»)." Kultura slova (Word culture) 55-56 (2000): 26-30. Print.

9. Sverdan, T. "Usicheni frazeolohizmy u trylohii B. Lepkoho «Mazepa» (Truncated Idioms in B. Lepky's Trilogy "Mazepa")." Dyvoslovo 1 (1999): 14-17. Print.

10. Sytar, Hanna. Syntaksychni Frazeolohizmy v Rozrizi Konstruktsiinoi Hramatyky (Syntactic Idioms in the Context of Construction Grammar). Vinnytsya, 2017. Print.

11. Sytar, H. V. Syntaksychni Frazeolohizmy v Ukrayins'kiy Movi: Strukturno-semantychnyy, Prahmatychnyy i Prykladnyy Vymiry (Syntactic Idioms in the Ukrainian Language: Structural-semantic, Pragmatic and Applied Dimensions.) Diss. Donetsk National U, Taras Shevchenko Kyiv National University. 2017. Vinnytsya - Kyiv. 2017. Print.

12. Sytar, Hanna. "Syntaksychni Frazeolohizmy v Linhvopersonolohiinomu Portreti Mykhaila Kotsiubynskoho (Syntactic Idioms in the Linguo-personological Portrait of Mykhailo Kotsyubynskiy)." Teoriia Linhvistychnykh Paradyhm (Theory of Linguistic Paradigms) Vinnytsia : TOV «Nilan LTD», 2019. 172-195. Print.

13. Sytar, Hanna. "Syntaksychni Frazeolohizmy yak Skladnyk Linhvopersonolohiinoho Portretu Yuriia Shevelova (na materiali korpusu tekstiv Yuriia Shevelova) (Syntactic Idioms as a Compo- 
nent of George Y. Shevelov`s Lingvopersonological Portrait: on the Material of George Y. Shevelov`s Texts Corpus).” Linhvistychni studii (Linguistic Studies) 37 (2019): 130-134. Print.

14. Sytar, Hanna. "Realizatsiia Modelei Frazeolohizovanykh Rechen u Tvorakh Iren Rozdobudko (Implementation of Models of Phraseologized Sentences in the Works of Irene Rozdobudko)." Theoretical and Empirical Scientific Research: Concept and Trends : Collection of Scientific Pa-

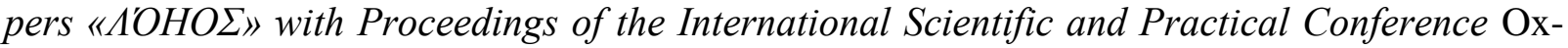
ford, United Kingdom: Oxford Sciences Ltd. \&European Scientific Platform. Vol. 3 (2020): 154155. Print.

15. Tkachuk, T. I. Movnostylistychna Orhanizatsiia Istorychnoho Prozovoho Tekstu (na Materiali Tetralohii Bohdana Lepkoho «Mazepa») (Linguistic Organization of Historical Prose Text (Based on the Tetralogy of Bohdan Lepkyi «Mazepa»). Diss. Kyiv, 2011. Abstract. Print.

16. Velichko, Alla. Sintaksicheskaya frazeologiya dlya russkikh $i$ inostrantsev (Syntactic Phraseology for Russions and Foreigners). Moscow: Moscow State Univ., 1996. Print.

17. Vsevolodova, M. V. Teoriya Funkcional'no-Kommunikativnogo Sintaksisa. Fragment Prikladnoj (Pedagogicheskoj) Modeli Yazyka (Theory of Functional Communicative Syntax. A Fragment of an Applied (Pedagogical) Language Model). Moscow, 2017. Print.

18. Vsevolodova, M. V., and Yon Lim Su. Printsipy Lingvisticheskogo Opisaniya Sintaksicheskikh Frazeologizmov: Na Materiale Sintaksicheskikh Frazeologizmov so Znacheniem Otsenki (The Principles of Linguistic Description of Syntactic Idioms : Based on the Syntactic Idioms with Evaluative Meaning). Moscow, 2002. Print.

19. Zahnitko, A. P. Teoriia Linhvopersonolohii (The Theory of Lingvopersonology). Vinnytsia: Nilan-Ltd, 2017. Print.

20. Zdikhovska, T.V. Frazeolohiia Prozovykh Tvoriv Ulasa Samchuka ta Bohdana Lepkoho (Phraseology of Prose Works by Ulas Samchuk and Bohdan Lepkyi). Lutsk : Vezha-Druk, 2014. Print.

21. Zdikhovska, T. V. Frazeolohiia Ukrainskoi Prozy Pershoi Polovyny XX st. (na Materiali Tvoriv U. Samchuka ta B. Lepkoho) (The Phraseology of Ukrainian Prose of the First Half of the XXieth Century (Based on the Works of U. Samchuk and B. Lepkyi). Diss. Lutsk, 2010. Print.

22. Zdikhovska T.V., Horbach N. V. "Vyhukovi Frazeolohizmy z Emotsiino-Ohtsinnym Znachenniam u Prozi B. Lepkoho ta U. Samchuka: Semantychnyi i Funktsiino-Stylistychnyi Aspekty (Exclamation phraseologisms with emotional and evaluative value in prose of B. Lepkyi and U. Samchuk: semantic, stylistic and functional aspects)." Naukovi zapysky Natsionalnoho universytetu «Ostrozka akademiia». Seriia «Filolohichna» (Scientific notes «Philology») 65 (2017): 116-119. Print.

23. Zdikhovska, T. V. "Funktsionalno-Stylistychni ta Semantychni Vlastyvosti Frazeolohizmiv na Poznachennia Emotsiinykh Staniv Liudyny v Prozi Bohdana Lepkoho (Functional-Stylistic and Semantic Properties of Phraseology to Denote Emotional States of Person in the Prose of Bohdan Lepkyi)." Naukovyi visnyk SNU imeni Lesi Ukrainky 6 (283): 79-83. Print.

\section{Джерела ілюстративного матеріалу}

Корпус текстів Богдана Лепкого / Укладач: Віка Кітаєва.

URL: http://corpora.donnu.edu.ua/bonito/run.cgi/corp_info?corpname=kitaeva (дата звернення: 1.08.2020).

\section{List of Sources}

Text Corpus by Bohdan Lepkyi / Compiler: Vika Kitaieva. URL: http://corpora.donnu.edu.ua/bonito/run.cgi/corp_info?corpname=kitaeva Web. 1 Aug. 2020. 


\section{THE REALIZATION PECULIARITIES OF SYNTACTIC IDIOMS MODELS IN BOHDAN LEPKYI'S WORKS \\ Hanna Sytar}

Department of General and Applied Linguistics and Slavonic Philology, Vasyl' Stus Donetsk National University, Vinnytsia, Ukraine

\section{Abstract}

Background: The article is devoted to the analysis of syntactic idioms in the prose texts of the outstanding Ukrainian writer Bohdan Lepkyi. The study was performed within the fundamental research project "Objective and subjective linguistic-social grammar: communicative-cognitive and pragmatic-linguocomputer dimensions" (0118U003137) Vasyl Stus Donetsk National University of the Ministry of Education and Science of Ukraine on the material of the writer's text corpus (http://corpora.donnu.edu.ua/bonito/run.cgi/corp_info?corpname=kitaeva).

Purpose: The purpose of the research is to reveal the realization peculiarities of syntactic idioms models in Bohdan Lepkyi's works.

Results: Syntactic idioms in the writer's prose texts are the bright instrument of expressive syntax, by which the author conveys evaluative, modal, negative, or accentual meaning. Bohdan Lepkyi uses 18 syntactic idioms models, the most productive are: Який (уже/вже/же/ж) $\mathrm{N}_{1} \mathrm{Cop}_{\mathrm{f}}$,

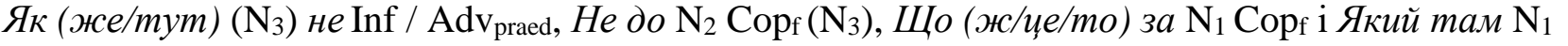
Cop . Some models are represented by single examples: До чого $\mathrm{N}_{1} \operatorname{Cop}_{\mathrm{f}} \operatorname{Adj}_{1}, O m\left(\mathrm{~N}_{3}\right) \mathrm{N}_{1} \operatorname{Cop}_{\mathrm{f}} \mathrm{i}$ Чому $б\left(\mathrm{~N}_{3}\right)$ не Inf. If we talk about the number of components, the models with a two-part core dominate, if we talk about the part-of-speech core component status, the models with compound particles rules.

As multifunctional items, the syntactic idioms in Bohdan Lepkyi's texts perform expressive, phatic, corrective, and argumentative functions.

Discussion: The diversity in morphological content, in the number of components within the core, in the realized semantics and functions of syntactic idioms is evidence of the richness of Bohdan Lepkyi's syntax and connection with colloquial speech. At the same time, the selectivity of the syntactic idioms models usage (18 of 105 possible models) makes it possible to classify them as syntactic markers of personality speech.

The feature of Bohdan Lepkyi's speech is the stringing of syntactic idioms, built on one or different structural schemes.

The prospects for further research are to pick out other identifiers of individual speech at the syntactic level.

Keywords: Bohdan Lepkyi, text corpus, linguistic personality, model of sentence, pragmatics, semantics, sentence with phraseological structure, syntax, syntactic idiom, phraseology.

\section{Vitae}

Hanna Sytar is Doctor of Philology, Associate Professor, Professor of Department of General and Applied Linguistics and Slavonic Philology at Vasyl' Stus Donetsk National University. Her areas of research interests include syntax, semantics, pragmatics, construction grammar, applied linguistics.

Correspondence: h.v.sytar@donnu.edu.ua 